\title{
Biological Risk Assessment of Heavy Metals in Sediments and Health Risk Assessment in Marine Organisms from Daya Bay, China
}

\author{
Zexing Kuang ${ }^{1,2} \mathbb{D}$, Yangguang $G u^{1,3}$, Yiyong Rao ${ }^{1,3}$ and Honghui Huang ${ }^{1,3, *}$ \\ 1 Guangdong Provincial Key Laboratory of Fishery Ecology and Environment, South China Sea Fisheries \\ Research Institute, Chinese Academy of Fishery Sciences, Guangzhou 510300, China; \\ kuangzexing@outlook.com (Z.K.); sunshinegu@scsfri.ac.cn (Y.G.); raoyiyong@scsfri.ac.cn (Y.R.) \\ 2 College of Fisheries and Life Science, Shanghai Ocean University, Shanghai 201306, China \\ 3 Southern Marine Science and Engineering Guangdong Laboratory (Guangzhou), Haibin Road, \\ Guangzhou 511485, China \\ * Correspondence: huanghh@scsfri.ac.cn
}

Citation: Kuang, Z.; Gu, Y.; Rao, Y.; Huang, H. Biological Risk Assessment of Heavy Metals in Sediments and Health Risk Assessment in Marine Organisms from Daya Bay, China. J. Mar. Sci. Eng. 2021, 9, 17. https://dx.doi.org/ 10.3390/jmse9010017

Received: 30 November 2020 Accepted: 22 December 2020 Published: 25 December 2020

Publisher's Note: MDPI stays neutral with regard to jurisdictional claims in published maps and institutional affiliations.

Copyright: () 2020 by the authors. Licensee MDPI, Basel, Switzerland. This article is an open access article distributed under the terms and conditions of the Creative Commons Attribution (CC BY) license (https: / / creativecommons.org/ licenses/by/4.0/).

\begin{abstract}
The concentrations of heavy metals in sediments and marine organisms in Daya Bay were investigated, and the Monte Carlo method was used to analyze the uncertainty of the results of geo-accumulation characteristics and ecological and health risks. The mean concentrations of metal elements in sediments were in the following order: $\mathrm{Zn}>\mathrm{Cr}>\mathrm{Cu}>\mathrm{As}>\mathrm{Cd}>\mathrm{Hg}$, while those in marine organisms were $\mathrm{Zn}>\mathrm{Cu}>\mathrm{As}>\mathrm{Cr} \approx \mathrm{Cd}>\mathrm{Hg}$. The geo-accumulation index (Igeo) indicated that the primary pollutant was $\mathrm{Hg}$, with $5.46 \%$ moderately polluted, and $39.52 \%$ for unpolluted to moderately polluted. Potential ecological risks (RI) were between low and high risks, and the contributions of $\mathrm{Hg}, \mathrm{Cd}$, and As to ecological risks were $50.85 \%, 33.92 \%$, and $11.47 \%$, respectively. The total hazard coefficients (THQ) were less than 1, but on the basis of total carcinogenic risks (TCR), the probability of children and adults exceeded the unacceptable risk threshold of $22.27 \%$ and $11.19 \%$, respectively. Sensitivity analysis results showed that the concentrations of carcinogenic elements contributed to risk in the order of $\mathrm{As}>\mathrm{Cd}>\mathrm{Cr}$. Therefore, in order to effectively control heavy metals contamination in Daya Bay, it is necessary to strengthen the management of $\mathrm{Hg}, \mathrm{Cd}$, and As emissions.
\end{abstract}

Keywords: heavy metals; ecological risk; human health risk; Monte Carlo; Daya Bay

\section{Introduction}

The impact of heavy metal pollution on the sustainability of biogeochemical cycles and ecological risks has received increasing global attention [1]. Heavy metals have special eco-toxicological effects, such as toxicity, accumulation, and refractory degradation [2]. When heavy metals enter the aquatic environment, they eventually accumulate in sediments, so sediments are usually used as a main medium for evaluating heavy metal pollution [3]. However, when the environmental conditions change, these are released from the sediments, and then used as a source to return to the overlying water, threatening the aquatic environments and marine organisms [2,4,5]. Marine organisms are rich in proteins, low saturated fatty contents and Omega-3 fatty acids, and other nutrients needed by the human body [6]. However, due to the enrichment and amplification of heavy metals in marine organisms, seafood that originally provided the human body with abundant protein may become a carrier of concentrated poisons, thereby endangering human health [7-11]. Therefore, identifying the concentration distribution of heavy metals in sediments and marine organisms and assessing the ecological and health risks under heavy metal exposure are of great significance to the protection of biological habitats and human safety. 
Daya Bay is a semi-enclosed bay in the northwest of the South China Sea and is a key protected area for fishery resources [5,6]. Since the 1980s, with the rapid development of industrialization and urbanization, as well as the rapid growth of population, Daya Bay has been affected by many aspects of pollution, such as aquaculture, port, petrochemical, nuclear power plant, wind power plant, etc. $[12,13]$. Moreover, there are reports that since the construction of the nuclear power plants, the concentrations of metal elements in sediment cores of Daya Bay had been dramatically increased [14,15]. Gu et al. [12] proposed that the "hot spot" area in the Daya Bay near the nuclear power plants seems to have contributed metallic elements through nuclear waste discharge to the sediments in study area. Although many scholars have conducted studies on the seawater, sediments, and heavy metal pollution of marine organisms in Daya Bay and reported their ecological or health risks $[5,6,10,13,16,17]$, there has been no targeted research on the pollution of existing nuclear power plant sources, or the sampling density has been insufficient. Thus, there is an urgent need for improved high-resolution heavy metal index sampling in the sea area surrounding the nuclear power plants in the Daya Bay. In this study, we adopted the Monte Carlo method to obtain large samples of heavy metals index data through statistical sampling experiments on the computer to accommodate uncertainties associated with risk-related problems [18]. The purposes of this study were (1) to develop a combination of traditional evaluation models and Monte Carlo simulation to optimize the uncertainty of risk assessment; (2) investigate the concentration distribution and pollution of heavy metals in the sediments and marine organisms in the sea area surrounding the nuclear power plants in the Daya Bay; and (3) examine toxic effects and risk assessment under exposure of heavy metals.

\section{Materials and Methods}

\subsection{Study Area and Samples Collection}

The study area is located in the southwestern region of Daya Bay in Guangdong Province, South China. In January and March 2020, 27 surface sediment samples and 20 species of marine organism samples were collected, respectively (Figure 1). The sediment samples were collected by precleaned stainless steel grab sampler, and two sediment samples were collected at each site to prepare a mixed sample. Marine organisms were collected by horizontal trawl and intertidal surveys, and selected adult individuals as samples. The details of organism samples are shown in Table S1. All samples collected from Daya Bay were placed in polyethylene sealed bags and stored at $-4{ }^{\circ} \mathrm{C}$ until processing and analysis.

\subsection{Chemical Analysis and Quality Assurance}

The sediment samples were freeze-dried to a constant weight, ground with an agate mortar and pestle, passed through a $63 \mu \mathrm{m}$ sieve, and stored at $-20{ }^{\circ} \mathrm{C}$ in brown glass bottles. Heavy metal microwave digestion was conducted in accordance with the EPA Method 3050B using an Ethos Plus Microwave Labstation (Milestone Inc., Italy).

The marine organism samples were first thawed naturally at room temperature, then rinsed with deionized water for 3-5 times. The edible tissues were removed from each organism with stainless steel scissors and a scalpel, tissues form organisms of the same species were mixed together thoroughly, crushed with a stainless steel mixer, freeze-dried to constant weight, and ground to give a homogeneous powder, which was stored in a brown glass bottle at $-20{ }^{\circ} \mathrm{C}$. An aliquot of each dried and homogenized sample was digested using a microwave digestion system. The metal extraction procedure is described in detail elsewhere [1].

The quality control and assurance of sediment samples were carried out by using the standard recovery method. The recoveries of the metals were between $83 \%$ and $111 \%$. The Chinese National Standard material (offshore marine sediment, GBW 07314) were analyzed together. 

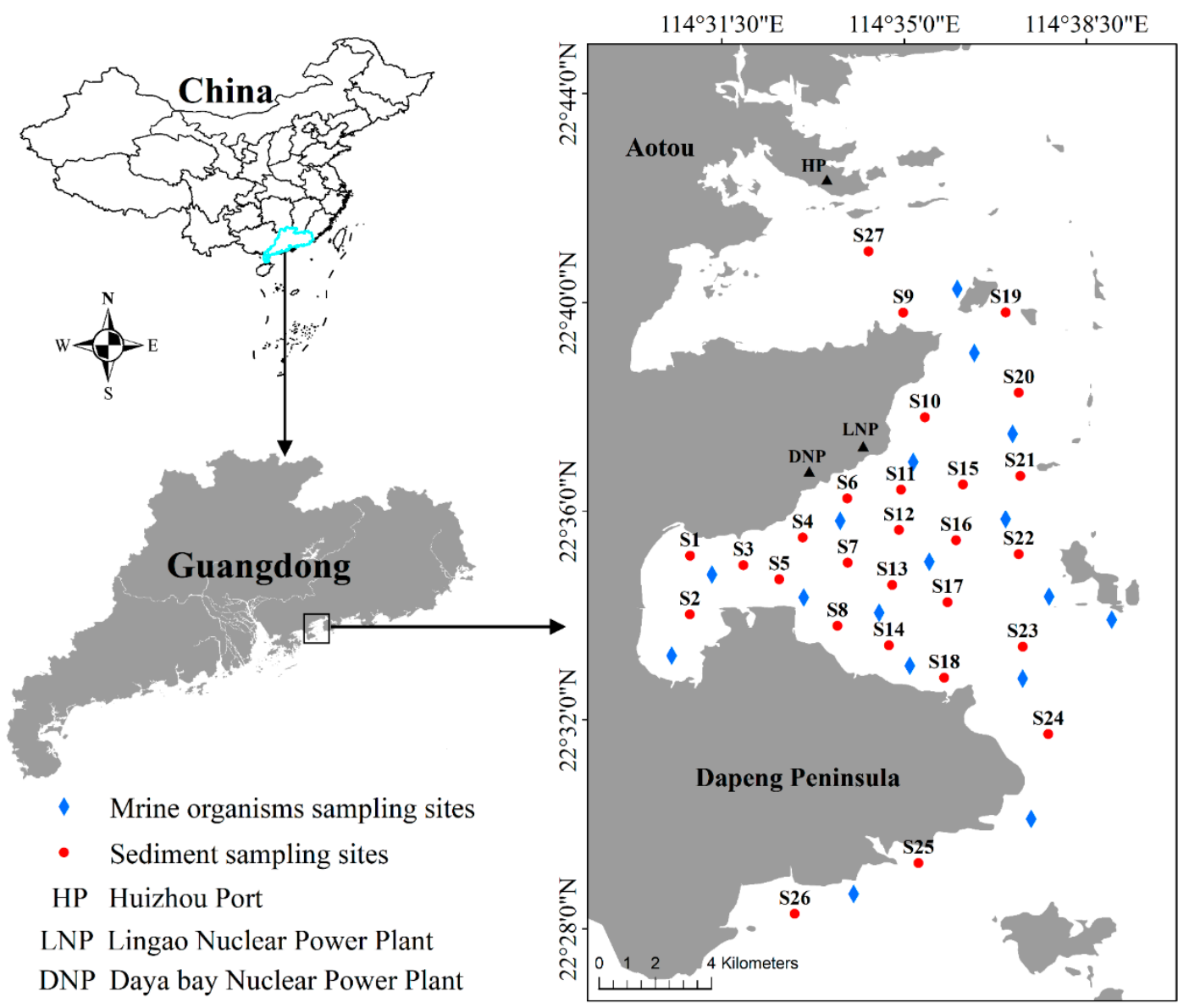

Figure 1. Location of Daya Bay and the sampling sites.

Reagent blanks were used to correct the analyses results of marine organism samples. The concentration of all seven metals in the standard muscle tissue reference material 2976 (for trace elements and methylmercury) supplied by the United States National Institute of Standards and Technology (Gaithersburg, MD, USA) were determined, as well as on samples for quality control. The recoveries of the metals were between $80 \%$ and $120 \%$. The $\mathrm{Cu}, \mathrm{Zn}, \mathrm{Cd}$, and $\mathrm{Cr}$ concentrations in samples were measured by an atomic absorption spectrophotometer (AAS-Z2000; Hitachi, Tokyo, Japan) and the As and Hg concentrations were measured by an atomic fluorescence spectrophotometer (AFS-9700; Haiguang Instruments, Beijing, China).

\subsection{Evaluation Methods}

\subsubsection{Assessment of Sediment Contamination}

The index $I_{\text {geo }}$ has been widely used to assess heavy metal contamination in sediment and soil $[19,20]$. The $I_{g e o}$ values were calculated by using the following equation:

$$
I_{\text {geo }}=\log _{2}\left[C_{n} /\left(1.5 B_{n}\right)\right]
$$

where $C_{n}$ represents the measured concentration of heavy metals and $B_{n}$ represents the background reference concentration. Due to lack of data on background values for the study area, element abundances of the upper continental crust were used as the background reference [19]. For this, 1.5 was the background matrix correction factor due to lithogenic effects. The geo-accumulation index can be divided into 7 categories, as shown in Table S2. 
The methodology developed by Hakanson was used to calculate the potential ecological risk (RI) of Daya Bay [21].

$$
\begin{gathered}
\mathrm{C}_{\mathrm{f}}^{\mathrm{i}}=\mathrm{C}_{\mathrm{i}} / \mathrm{B}_{\mathrm{i}} \\
\mathrm{E}_{\mathrm{r}}^{\mathrm{i}}=\mathrm{T}_{\mathrm{r}}^{\mathrm{i}} \times \mathrm{C}_{\mathrm{f}}^{\mathrm{i}} \\
\mathrm{RI}=\sum \mathrm{E}_{\mathrm{r}}^{\mathrm{i}}
\end{gathered}
$$

where $C_{i}$ and $B_{i}$ represent the determined concentration and reference standard value of heavy metals, respectively. $\mathrm{C}_{\mathrm{f}}^{\mathrm{i}}$, the pollution index of an individual element; $\mathrm{T}_{\mathrm{r}}^{\mathrm{i}}$, the toxicity coefficient of heavy metals, for $\mathrm{Cu}, \mathrm{Zn}, \mathrm{Cr}, \mathrm{Cd}, \mathrm{As}$, and $\mathrm{Hg}$ were 5, 1, 2, 30, 10, and 40, respectively [22]; and $\mathrm{E}_{\mathrm{r}}^{\mathrm{i}}$ is the ecological risk coefficient of an individual element.

\subsubsection{Health Risk Models}

Marine organisms accumulate heavy metals through respiration and ingestion, and heavy metals may endanger human health through the food chains. This study used health risk assessment index to evaluate the edible health risks of Daya Bay organisms. The calculation method was as follows:

$$
\begin{gathered}
\mathrm{EDI}=\frac{\mathrm{C}_{\mathrm{m}} \times \mathrm{IR} \times \mathrm{EF} \times \mathrm{ED}}{\mathrm{AT} \times \mathrm{BW}} \times \mathrm{AR}_{\mathrm{m}} \\
\mathrm{HQ}=\mathrm{EDI} / \mathrm{R} f \mathrm{DCR}=\mathrm{EDI} \times \mathrm{SF} \\
\mathrm{THQ}=\mathrm{HQ}_{1}+\mathrm{HQ}_{2}+\ldots+\mathrm{HQ}_{\mathrm{n}} \\
\mathrm{TCR}=\mathrm{CR}_{1}+\mathrm{CR}_{2}+\ldots+\mathrm{CR}_{\mathrm{n}}
\end{gathered}
$$

where $C_{m}$ is the concentration of heavy metals in marine organisms $(\mathrm{mg} / \mathrm{kg}$ ) and IR is the ingestion rate of seafood ( $\mathrm{g} /$ person/day). The daily consumption of seafood in Guangdong Province is $51 \mathrm{~g}$ for an adult, and the ingestion rate for children is estimated to be $26.5 \%$ of that of adults [23]. BW is the average body weight (adults: $70 \mathrm{~kg}$; children: $15 \mathrm{~kg}$ ) [24], EF and ED indicate the exposure frequency (365 day/year) and exposure duration (adults: 70 years; children: 6 years), respectively. AT is the total exposure time (adults: 25,550 days; children: 2190 days). $\mathrm{AR}_{\mathrm{m}}$ is the intestinal absorption rate of heavy metals, the values of $\mathrm{AR}_{\mathrm{m}}$ for $\mathrm{Cu}, \mathrm{Zn}, \mathrm{Cd}, \mathrm{Cr}, \mathrm{Hg}$ and $\mathrm{As}$ were $45 \%, 65 \%, 75 \%$, $55 \%, 64 \%$, and $75 \%$, respectively $[25,26]$. RfD is the chronic reference dose, the chronic reference doses of $\mathrm{Cu}, \mathrm{Zn}, \mathrm{Cd}, \mathrm{Cr}, \mathrm{Hg}$ and As were $0.04,0.3,0.001,0.003,0.0001$, and 0.0003 $\mathrm{mg} / \mathrm{kg} /$ day, respectively; $\mathrm{SF}$ is the carcinogenic slope factor, based on values of $0.38,0.5$, and $1.5 \mathrm{mg} / \mathrm{kg} /$ day for $\mathrm{Cd}, \mathrm{Cr}$, and As, respectively [10]. Moreover, EDI indicates the established daily intake, $\mathrm{HQ}$ is the noncarcinogenic hazard quotient of heavy metals to human body (THQ indicates the total hazard quotient), and CR is the carcinogenic risk quotient (TCR indicates the total carcinogenic risk). In addition, the As concentration in this study was the total content, but previous studies on the health risks of As reported that only inorganic As posed threats to humans, and the inorganic As was assumed to be $10 \%$ of the total As [27].

\subsection{Monte Carlo Simulation}

When the uncertainty arises owing to lack of knowledge of the metal concentrations and variability of toxic response among individuals, the probability approximate solution obtained by Monte Carlo simulation can enhance the understanding of the environmental behavior of contaminants and show the uncertainties $[28,29]$. To capture variations of risk analysis in Guangdong costal, Monte Carlo simulation was used to handle the uncertainty of heavy metal concentrations in surface sediments and marine organism samples collected in Daya Bay. Simultaneously, sensitivity analysis was carried out to estimate the contribution of the exposure variables of the total risks to discern critical exposure factors. The main steps of Monte Carlo simulation are as following: (1) determine the random variables selected by the evaluation model; (2) define the distribution models of the random variables; and (3) sample randomly from the above distribution of the variables and output the simulation results. The concentrations of heavy metals in sediments and 
organism samples were transformed by natural logarithm to satisfy normality, indicating that the concentration data obey lognormal distribution (Table S3). Although, IR and BW, exposure time parameters (e.g., EF, ED, and AT) and toxicity criteria of heavy metals (e.g., $\mathrm{R} f \mathrm{D}$ and SF) could also have been changed, the current study only considered the impact of exposed heavy metal concentrations on risks, thus other exposure parameters were single-point inputs.

\subsection{Statistical Analysis}

SPSS (version 24.00) was used to transform the metal concentration data into natural logarithm and Q-Q plot was used to evaluate the normality of the dataset of each variable. Monte Carlo simulation was performed using Oracle Crystal Ball (version 11.1.4323.0) loaded in Microsoft Excel to run 10,000 times to obtain stable risk outputs and sensitivity index. ArcGIS 10.2 and OriginPro 2017 were used for graphics delineation.

\section{Results and Discussion}

\subsection{Heavy Metal Concentrations in Sediments}

The concentrations of $\mathrm{Cu}, \mathrm{Zn}, \mathrm{Cd}, \mathrm{Cr}, \mathrm{Hg}$, and As in sediments of Daya Bay were in the ranges of 5.3-44.5, 37.1-109.0, 0.06-0.22, 13.6-72.5, 0.014-0.171, and $4.8-9.7 \mathrm{mg} / \mathrm{kg}$, respectively (Table 2). The mean concentrations of these elements followed a decreasing order: $\mathrm{Zn}>\mathrm{Cr}>\mathrm{Cu}>\mathrm{As}>\mathrm{Cd}>\mathrm{Hg}$. From the perspective of coefficient of variation (CV), $\mathrm{Hg}$ and $\mathrm{Cu}$ reached the $\mathrm{CV}$ level of $49 \%$ and $47 \%$, respectively, and the coefficients of variation of other elements were between $14 \%$ and $31 \%$. The results of descriptive statistics indicated that the metal concentrations in sediments of Daya Bay were quite different, and there was a large uncertainty in the spatial distribution of the metal concentration levels. Compared with the limited values of Chinese Marine Sediment Quality Standard (GB186682002), most of the concentration levels were lower than the corresponding limits. The mean concentrations of $\mathrm{Zn}, \mathrm{Cd}, \mathrm{Hg}$, and As were slightly higher than their background values, indicating the impact of human activities. Threshold effect level (TEL) and probable effect level (PEL) could be used to evaluate the environmental risk caused by heavy metals in sediments. When concentrations of metals in sediments are lower than TEL, adverse effects upon sediment dwelling fauna will be infrequent, while when the PEL is exceeded, adverse harmful effects on sediment-dwelling organisms are expected to occur frequently [30]. The concentrations of heavy metal in the sediments of Daya Bay were lower than TEL or between TEL and PEL.

Comparing the results of this study with the studies of the Daya Bay in different periods (Table 1), it could be found that all concentrations of metals in sediments after 2008 were higher than those in 1988 [5]. From 2008 to 2020, the metals concentrations showed a law of first decline, then increase, and then decrease $[5,13,19]$. The trend of regular fluctuations reflected the impact of urban development and the government's corresponding environmental management policies on heavy metal contamination in sediments of Daya Bay. However, the results of the one-way analysis of variance showed that there was no significant difference in the concentrations of heavy metals from 1988 to $2020(p>0.05)$, which seems to indicate that the contribution of nuclear power plants sources to the contents of heavy metals in the sediment is limited. Compared with other bays along the coast of China, the levels of heavy metal concentration in Daya Bay were slightly higher than Beibu Gulf [20], but lower than Liaodong Bay, Bohai Bay, Jiaozhou Bay, Zhoushan Bay, and Quanzhou Bay [31-35]. 
Table 1. Comparison of heavy metal concentrations in sediments from Daya Bay with other regions $(\mathrm{mg} / \mathrm{kg})$.

\begin{tabular}{|c|c|c|c|c|c|c|c|c|}
\hline Study Area & Sampling Date & $\mathrm{Cu}$ & Zn & $\mathrm{Cd}$ & $\mathrm{Cr}$ & $\mathrm{Hg}$ & As & Reference \\
\hline Daya Bay & 1988 & 6.44 & 26.01 & 0.03 & 22.35 & NA & 2.61 & [5] \\
\hline Daya Bay & 2008 & 16.46 & 87.81 & 0.07 & 59.03 & 0.04 & 8.16 & [19] \\
\hline Daya Bay & 2011 & 10.4 & 59.34 & 0.04 & 30.03 & NA & 7.01 & [13] \\
\hline Daya Bay & 2016 & 24.58 & 111.65 & 0.23 & 65.04 & NA & 12.41 & [5] \\
\hline Daya Bay & 2020 & 15.1 & 79.8 & 0.13 & 36.1 & 0.08 & 7.16 & This study \\
\hline Liaodong Bay & 2013 & 19.66 & 70.2 & 0.22 & 61.5 & 0.06 & 9.28 & [34] \\
\hline Bohai Bay & 2016 & 32.6 & 95.2 & 0.3 & 75.2 & 0.07 & 12.9 & [31] \\
\hline Jiaozhou Bay & 2015 & 27.31 & 76 & 0.3 & 86.17 & NA & NA & [33] \\
\hline Zhoushan Bay & 2017 & 27.22 & 103.09 & 0.19 & 68.62 & 0.03 & NA & [32] \\
\hline Quanzhou Bay & 2011 & 60.81 & 186.7 & 0.64 & 84.72 & 0.11 & NA & [35] \\
\hline Beibu Gulf & 2017 & 15.07 & 52.37 & 0.06 & 44.42 & 0.06 & 7.82 & [20] \\
\hline
\end{tabular}

NA: not available.

Table 2. Descriptive statistics of sediment concentrations and corresponding reference standards.

\begin{tabular}{|c|c|c|c|c|c|c|}
\hline \multirow{2}{*}{ Parameters } & \multicolumn{6}{|c|}{ Heavy Metal (mg/kg) } \\
\hline & $\mathrm{Cu}$ & Zn & Cd & $\mathrm{Cr}$ & $\mathrm{Hg}$ & As \\
\hline Range & $5.3-44.5$ & $37.1-109.0$ & $0.06-0.22$ & $13.6-72.5$ & $0.014-0.171$ & $4.8-9.7$ \\
\hline Mean \pm S.D. & $15.1 \pm 7.02$ & $79.8 \pm 18.46$ & $0.13 \pm 0.04$ & $36.1 \pm 11.36$ & $0.079 \pm 0.039$ & $7.16 \pm 0.99$ \\
\hline Median & 14.4 & 85.2 & 0.13 & 38.3 & 0.072 & 7.1 \\
\hline $\mathrm{CV}(\%)$ & $47 \%$ & $23 \%$ & $28 \%$ & $31 \%$ & $49 \%$ & $14 \%$ \\
\hline TEL $^{1}$ & 35.7 & 123 & 0.596 & 37.3 & 0.174 & 5.9 \\
\hline PEL $^{1}$ & 197 & 315 & 3.53 & 90 & 0.486 & 17 \\
\hline Background value ${ }^{2}$ & 28 & 67 & 0.09 & 92 & 0.05 & 5 \\
\hline Primary standard, China ${ }^{3}$ & 35 & 150 & 0.5 & 80 & 0.2 & 20 \\
\hline
\end{tabular}

Mean \pm S.D.: average values and standard deviation; CV: coefficients of variation. ${ }^{1}$ TEL: threshold effect level, PEL: probable effect level $[30,36] .{ }^{2}$ Element abundances of the upper continental crust [19]. ${ }^{3}$ Chinese Marine Sediment Quality Standard (GB 18668-2002).

\subsection{Heavy Metal Concentrations in Organisms}

Table 3 lists the overall heavy metal concentrations of 20 organism species collected in Daya Bay. Heavy metal concentrations $(\mathrm{mg} / \mathrm{kg}$, dry weight) ranged from 0.7 to 102.0 for $\mathrm{Cu}, 12.5-274.0$ for $\mathrm{Zn}, 0.011-1.690$ for Cd, 0.10-1.99 for Cr, 0.4-4.5 for As, and 0.015-0.147 for $\mathrm{Hg}$. The relative ranking order of the mean concentrations of overall marine organism samples were: $\mathrm{Zn}>\mathrm{Cu}>\mathrm{As}>\mathrm{Cr} \approx \mathrm{Cd}>\mathrm{Hg}$. The concentrations of mollusks in this study were similar to the results of previous study by Yuan et al. [10]. Comparing the mean concentrations of different marine organism groups indicated that mollusks had the highest $\mathrm{Cr}$ and As concentrations; crustaceans had the highest concentrations of $\mathrm{Cu}, \mathrm{Zn}$, and $\mathrm{Cd}$; and fish had the highest concentrations of $\mathrm{Hg}$. The variance in the concentration of heavy metals in different groups of organisms is related to their feeding patterns and nutritional levels $[8,26]$. Additionally, this study did not determine the sexes and reproductive stages of marine organisms, and the accumulation of metals in gonad tissues as well as in eggs at different embryonic development stages will have a slight impact on the statistical heavy metal contents of marine organisms [37,38]. In terms of the mean concentrations, the heavy metals concentrations in the marine organisms from Daya Bay basically met the safety standards of the Chinese National Standard of Maximum Levels of Contaminants in Food specifies (GB 2762-2017) and the safety standards of the FAO guidelines [39]. 
Table 3. Heavy metal concentrations ( $\mathrm{mg} / \mathrm{kg}$, dry weight) in 20 marine species from Daya Bay.

\begin{tabular}{|c|c|c|c|c|c|c|c|}
\hline \multirow{2}{*}{$\begin{array}{c}\text { Group of Marine } \\
\text { Organisms }\end{array}$} & \multirow{2}{*}{ Species } & \multicolumn{6}{|c|}{ Metal Concentrations } \\
\hline & & $\mathrm{Cu}$ & Zn & Cd & $\mathrm{Cr}$ & As & $\mathrm{Hg}$ \\
\hline \multirow{9}{*}{ Mollusks } & Perna viridis & 13 & 108 & 0.674 & 0.44 & 2.9 & 0.086 \\
\hline & Ruditapes philippinarum & 6.7 & 82.8 & 0.964 & 0.27 & 4.5 & 0.04 \\
\hline & Paphia undulata & 10 & 57.5 & 0.834 & 1.07 & 1.7 & 0.062 \\
\hline & Placamen calophylla & 12.4 & 51.7 & 1.09 & 1.99 & 3.3 & 0.056 \\
\hline & Bursa rana & 7.4 & 66.2 & 0.27 & 0.48 & 1.3 & 0.054 \\
\hline & Glossaulax didyma & 18.9 & 86.2 & 0.218 & 0.4 & 1 & 0.04 \\
\hline & Uroteuthis duvauceli & 16 & 44 & 0.15 & 0.14 & 0.6 & 0.04 \\
\hline & Mean & 12.06 & 70.91 & 0.60 & 0.68 & 2.19 & 0.05 \\
\hline & Miyakea nepa & 59.8 & 102 & 1.14 & 0.18 & 2.1 & 0.04 \\
\hline \multirow{4}{*}{ Crustaceans } & Harpiosquilla harpax & 102 & 99 & 1.69 & 0.29 & 2 & 0.018 \\
\hline & Portunus pelagicus & 72.6 & 130 & 0.108 & 0.48 & 1.6 & 0.015 \\
\hline & Charybdis hongkongensis Shen & 70.8 & 169 & 0.11 & 0.76 & 1.1 & 0.066 \\
\hline & Eucrata crenata & 60.2 & 274 & 0.063 & 0.24 & 1.3 & 0.062 \\
\hline \multirow{10}{*}{ Fish } & Mean & 73.08 & 154.80 & 0.62 & 0.39 & 1.62 & 0.04 \\
\hline & Nematalosa japonica & 8.1 & 30.7 & 0.093 & 0.2 & 0.4 & 0.017 \\
\hline & Osteomugil ophuyseni & 3.2 & 29.1 & 0.051 & 0.1 & 1.6 & 0.04 \\
\hline & Siganus canaliculatus & 2.5 & 26.4 & 0.062 & 0.18 & 0.9 & 0.036 \\
\hline & muraenesox cinereus & 1.3 & 17.6 & 0.027 & 0.15 & 0.9 & 0.054 \\
\hline & Sillago sihama & 1.1 & 20.4 & 0.026 & 0.16 & 0.9 & 0.138 \\
\hline & Pennahia anea & 3.3 & 20.6 & 0.015 & 0.14 & 0.9 & 0.054 \\
\hline & Gerres filamentosus & 1.5 & 39 & 0.014 & 0.16 & 0.8 & 0.147 \\
\hline & Saurida elongata & 0.7 & 12.5 & 0.011 & 0.1 & 0.5 & 0.141 \\
\hline & Mean & 2.71 & 24.54 & 0.04 & 0.15 & 0.86 & 0.08 \\
\hline \multicolumn{8}{|c|}{ Guidelines } \\
\hline \multirow{3}{*}{ China ${ }^{1}$} & Molluscs & NA & NA & 2 & 2 & 0.5 & 0.5 \\
\hline & Crustaceans & NA & NA & 0.5 & 2 & 0.5 & 0.5 \\
\hline & Fish & NA & NA & 0.1 & 2 & 0.1 & 0.5 \\
\hline \multirow{3}{*}{$\mathrm{FAO} / \mathrm{WHO}^{2}$} & Molluscs & 30 & 30 & 0.5 & NA & 1.5 & 0.5 \\
\hline & Crustaceans & 30 & 30 & 0.5 & NA & 1.5 & 0.5 \\
\hline & Fish & 30 & 30 & 0.5 & NA & 3.5 & 0.5 \\
\hline
\end{tabular}

1 The Chinese National Standard of Maximum Levels of Contaminants in Food specifies (GB 2762-2017). ${ }^{2}$ Food and Agriculture Organization, World Health Organization [39].

When comparing this study with the concentrations of heavy metals in marine organisms in other regions of the world, it was found that the concentrations of heavy metals in marine organisms varied widely in terms of regions and species (Table 4). Overall, the concentrations of $\mathrm{Cd}, \mathrm{Cr}$, and $\mathrm{Hg}$ in the marine organisms from Daya Bay were comparable to those in other regions, and the concentrations of As were much lower than those in Xiangshan Bay, Sanmen Bay, and Bangladesh coast. In addition, the concentrations of $\mathrm{Cu}$ and $\mathrm{Zn}$ in mollusks were also lower than those in other regions except the South China Sea. The geographical variation in heavy metal concentrations in marine organisms was commonly related to the local pollution status [40]. The high concentrations of metal elements in seawater and sediments contributed to the bioaccumulation of marine organisms [32].

\subsection{Contamination and Ecological Risk Assessment}

\subsubsection{Pollution Characteristics}

The Igeo values of heavy metals in sediments of the Daya Bay are listed in Figure 2, and ranged from -2.99 to 0.08 for $\mathrm{Cu}$ (average -1.60 ), -1.44 to 0.12 for $\mathrm{Zn}$ (average -0.38 ), -1.17 to 0.70 for Cd (average -0.14 ), -3.34 to -0.93 for $\mathrm{Cr}$ (average -2.01 ), -2.42 to 1.19 for $\mathrm{Hg}$ (average -0.14 ), and -0.64 to 0.37 for As (average -0.08 ). The average values of $\mathrm{I}_{\text {geo }}$ were arranged in descending order: $\mathrm{As}>\mathrm{Hg}=\mathrm{Cd}>\mathrm{Zn}>\mathrm{Cu}>\mathrm{Cr}$. The average values of $\mathrm{I}_{\text {geo }}$ of all elements were less than zero $\left(\mathrm{I}_{\text {geo }}<0\right)$, suggesting limited pollution of the Daya Bay. 


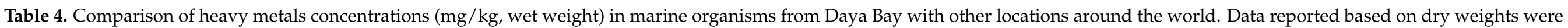
converted into wet weight by moisture contents [41].

\begin{tabular}{|c|c|c|c|c|c|c|c|c|}
\hline Sampling Area & Groups & $\mathrm{Cu}$ & Zn & Cd & $\mathrm{Cr}$ & As & $\mathrm{Hg}$ & References \\
\hline \multirow{3}{*}{ Daya Bay } & Molluscs & $1.3-3.8$ & $14.2-21.6$ & $0.120-0.218$ & $0.14-0.40$ & $0.4-0.9$ & $0.011-0.017$ & \multirow{3}{*}{ This study } \\
\hline & Crustaceans & $15.0-25.5$ & $24.8-68.5$ & $0.016-0.423$ & $0.05-0.19$ & $0.3-0.5$ & $0.004-0.017$ & \\
\hline & Fish & $0.2-2.4$ & $3.8-11.7$ & $0.003-0.028$ & $0.03-0.06$ & $0.1-0.5$ & $0.005-0.044$ & \\
\hline \multirow{2}{*}{ South China Sea } & Fish & $0.04-0.25$ & $1.05-2.14$ & $0.04-0.53$ & $0.40-0.86$ & NA & NA & {$[26]$} \\
\hline & Molluscs & $0.45-26.65$ & $8.34-65.72$ & $0.01-1.05$ & ND-2.89 & $0.42-15.9$ & $0.003-0.037$ & \multirow{3}{*}{ [42] } \\
\hline \multirow[t]{2}{*}{ Xiangshan Bay } & Crustaceans & $2.28-28.13$ & $9.58-51.22$ & $0.001-0.32$ & $0.02-2.14$ & $1.60-17.89$ & $0.001-0.25$ & \\
\hline & Fish & $0.14-0.47$ & $2.52-5.26$ & $0.0004-0.004$ & ND-0.21 & $0.16-8.04$ & $0.004-0.083$ & \\
\hline \multirow[t]{3}{*}{ Maowei Sea } & Crustaceans & $3.16-29.40$ & $9.57-34.35$ & $0.019-1.510$ & $0.10-0.23$ & $0.16-1.39$ & $0.016-0.045$ & \multirow[t]{2}{*}{ [43] } \\
\hline & Fish & $0.20-1.90$ & $10.50-40.50$ & $0.003-0.220$ & $0.12-0.63$ & $0.10-1.50$ & $0.006-0.028$ & \\
\hline & Molluscs & $0.92-96.81$ & $12.11-132.93$ & $0.18-9.64$ & $0.08-0.73$ & $1.42-20.94$ & $0.004-0.087$ & \multirow{3}{*}[44]{} \\
\hline \multirow[t]{2}{*}{ Sanmen Bay } & Crustaceans & $1.10-8.22$ & $12.59-59.31$ & ND-0.10 & $0.06-0.44$ & $2.90-10.36$ & $0.001-0.018$ & \\
\hline & Fish & $0.12-0.61$ & $2.38-8.34$ & ND-0.03 & $0.03-0.31$ & $0.53-2.04$ & $0.003-0.023$ & \\
\hline \multirow{2}{*}{ Bangladesh coast } & Crustaceans & $13-400$ & 53-1480 & $0.02-8.3$ & $0.29-29$ & $0.3-53$ & NA & \multirow{2}{*}[45]{} \\
\hline & Fish & $1.3-14$ & 31-138 & $0.03-0.09$ & $0.15-2.2$ & $0.8-13$ & NA & \\
\hline \multirow{2}{*}{ Saint Martin Island } & Crustaceans & $5.05-30.73$ & $7.02-61.92$ & $0.20-30.44$ & ND-1.41 & ND-0.28 & ND-0.05 & \multirow{2}{*}[7]{} \\
\hline & Fish & $0.3-2.23$ & $3.34-12.10$ & $1.52-14.09$ & $0.18-1.87$ & ND & $0.06-0.13$ & \\
\hline
\end{tabular}

ND: not detected. 


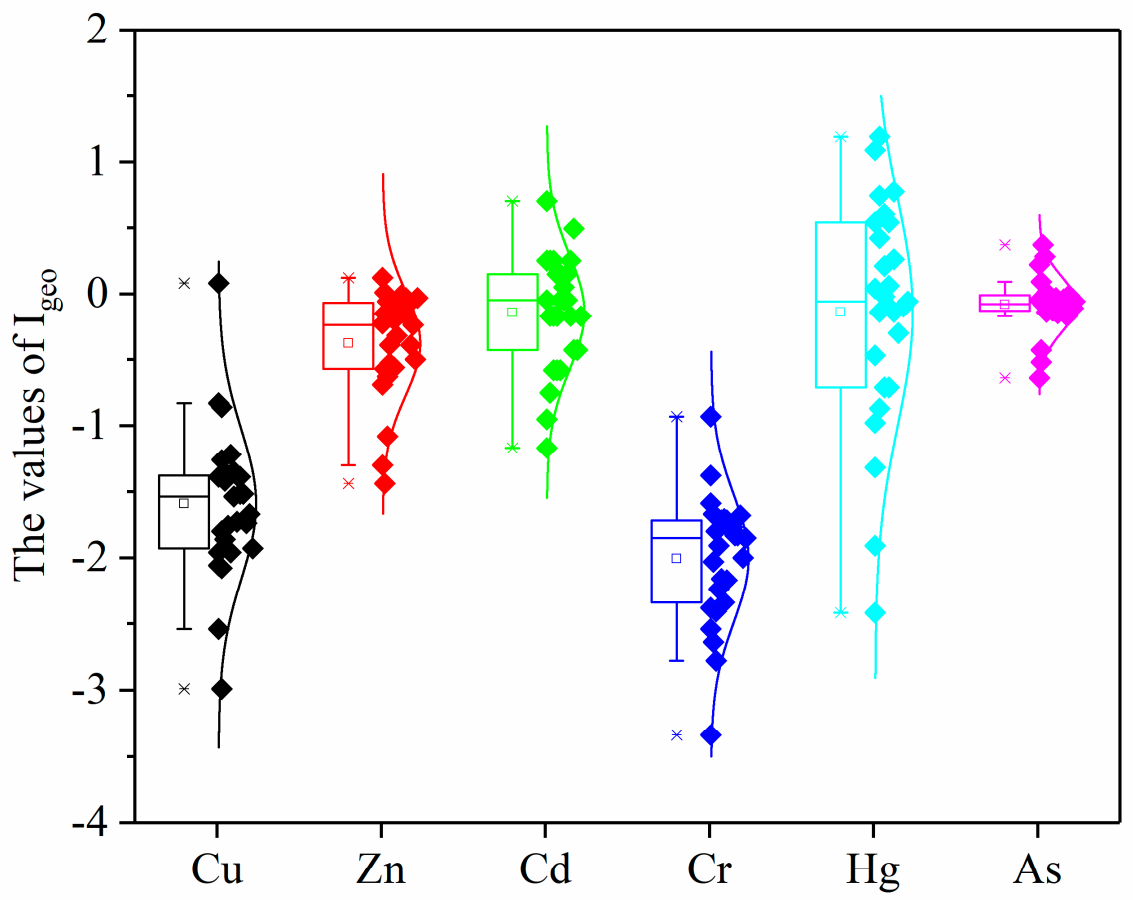

Figure 2. Geo-accumulation index $\left(\mathrm{I}_{\text {geo }}\right)$ of heavy metals in sediments of the Daya Bay.

For the contamination characteristics of heavy metals in the sediments of Daya Bay, the statistical results of random sampling based on the elements' concentrations distribution through Monte Carlo simulation and the class distribution of $\mathrm{I}_{\text {geo }}$ values are shown in Table $\mathrm{S} 4$ and Figure 3. The average values of $\mathrm{I}_{\text {geo }}$ were arranged in descending order: $\mathrm{Hg} \approx \mathrm{As}>$ $\mathrm{Cd}>\mathrm{Zn}>\mathrm{Cu}>\mathrm{Cr}$, and the average values of $\mathrm{I}_{\text {geo }}$ of all elements were less than zero, which is similar to the evaluation results based on the geo-accumulation index method. However, the class distribution of the $I_{g e o}$ values revealed that there was relative variance in the spatial distribution of heavy metal contamination. The $\mathrm{I}_{\text {geo }}$ value of $\mathrm{Hg}$ was the highest, with a moderately polluted score of $5.46 \%$ and unpolluted to moderately polluted score of $39.52 \%$, followed by $\mathrm{Cd}, \mathrm{As}$, and $\mathrm{Zn}$, with unpolluted to moderately polluted accounting for $35.71 \%, 34.78 \%$, and $12.76 \%$, respectively. $\mathrm{Hg}$ has no biological function, its most important sources are fuel combustion and coal combustion [12]. Previous studies reported that $\mathrm{Hg}$ and As in Daya Bay were affected by the same anthropogenic input [19], and Cd originated from the discharge of domestic sewage [13]. Therefore, heavy metals contamination in Daya Bay was closely related to nearby industrial and agricultural activities.

\subsubsection{Potential Ecological Risks}

Figure 4 illustrated the potential ecological risks of the heavy metals in sediments of Daya Bay. In general, the RI values of sampling sites varied significantly, ranging from 58.76 to 202.48. According to the category of RI (Table S5), five sampling sites reached a moderate risk and 22 sampling sites reached a low risk. In addition, Figure 4 shows that the $\mathrm{E}_{\mathrm{r}}^{\mathrm{i}}$ values of $\mathrm{Hg}$ had the highest contribution to potential ecological risks, followed by $\mathrm{Cd}$. The consequence of $\mathrm{E}_{\mathrm{r}}^{\mathrm{i}}$ values of the six heavy metals were ranked as $\mathrm{Hg}(62.81)>\mathrm{Cd}$ (42.47) > As (14.31) > Cu (2.69) > Zn (1.19) > Cr (0.79).

For the potential ecological risk characteristics, the cumulative probability of RI of heavy metals in sediments of Daya Bay based on Monte Carlo simulation were $80.94 \%$ for low risk, $18.96 \%$ for moderate risk, and $0.1 \%$ for high risk, respectively. High Igeo values also corresponded to high potential ecological risk indices. $\mathrm{Hg}, \mathrm{Cd}$, and As contributed $50.85 \%, 33.92 \%$, and $11.47 \%$ of the potential ecological risk, respectively (Figure $5 b$ ). It has been found in many studies that heavy metals negatively affect microbial community diversity [46]. Indirect ecological risks posed by changes in microbial communities are difficult to predict [47]. However, the concentrations of heavy metals, such as $\mathrm{Hg}$, measured 
in this study were relatively low, and did not exceed the primary standard of the China Marine Sediment Quality standards. Even at low concentrations, the comprehensive evaluation results of $\mathrm{I}_{\text {geo }}$ and RI showed that $\mathrm{Hg}$ was the primary heavy metal pollutant in sediments, followed by Cd and As. These results were similar to the study of Ding et al. [31]. From this point of view, $\mathrm{Hg}$ emissions in the Daya Bay area should be effectively controlled, and it is necessary to conduct ecological risk analysis and evaluation on the uncertainty of heavy metal emissions in the Daya Bay area.

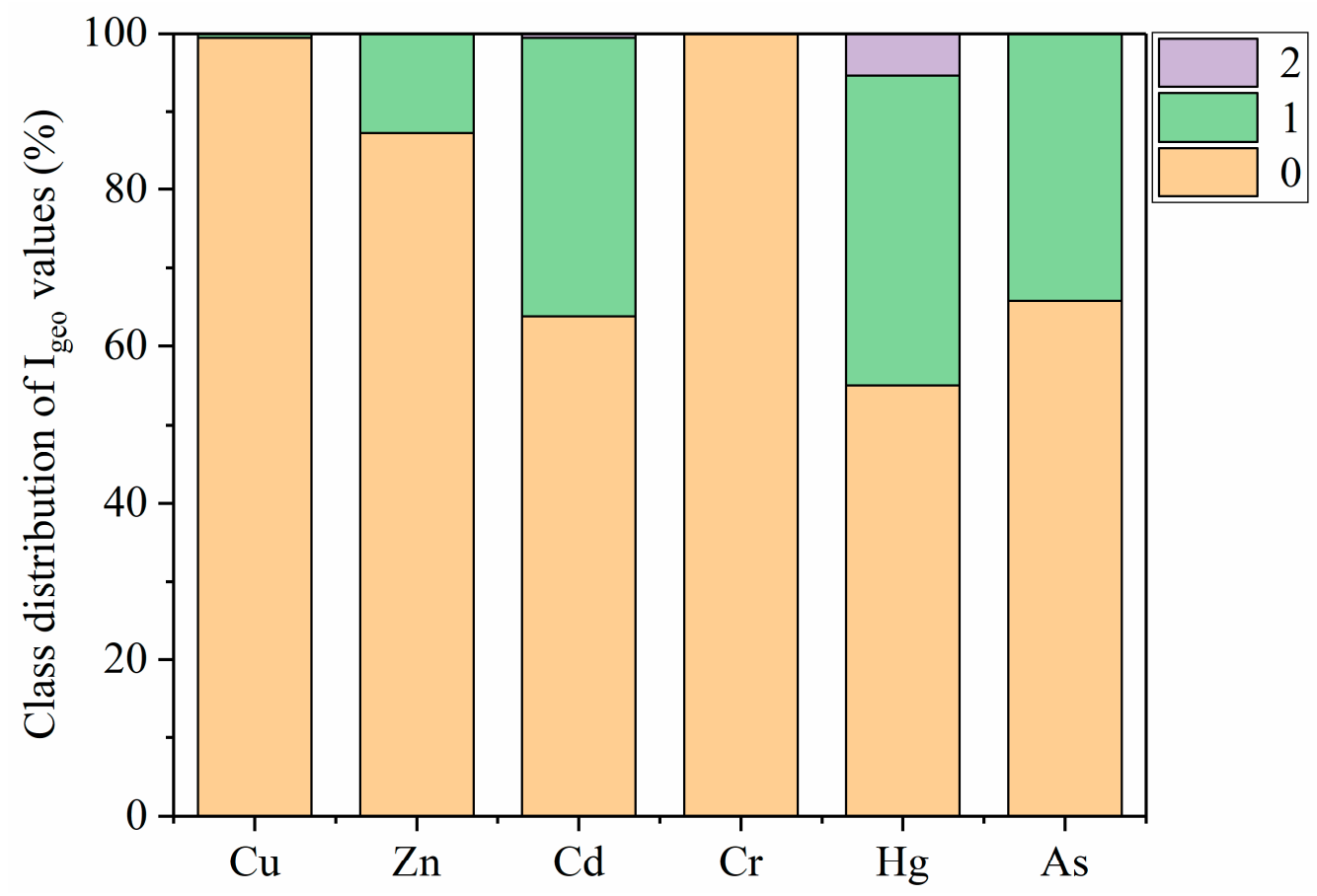

Figure 3. Class distribution of $\mathrm{I}_{\text {geo }}$ values of heavy metals in sediment of Daya Bay.

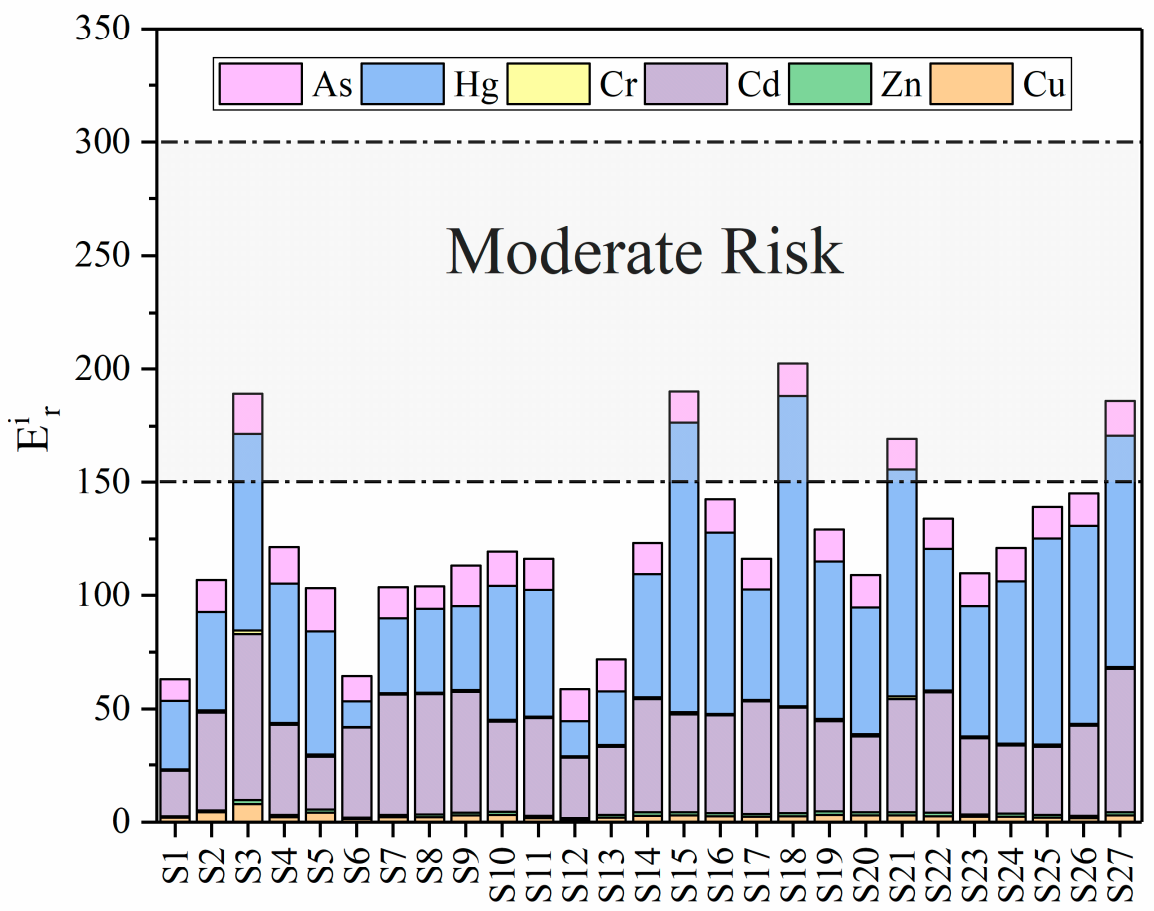

Figure 4. Potential ecological risk index (RI) of heavy metals in sediments of Daya Bay. 

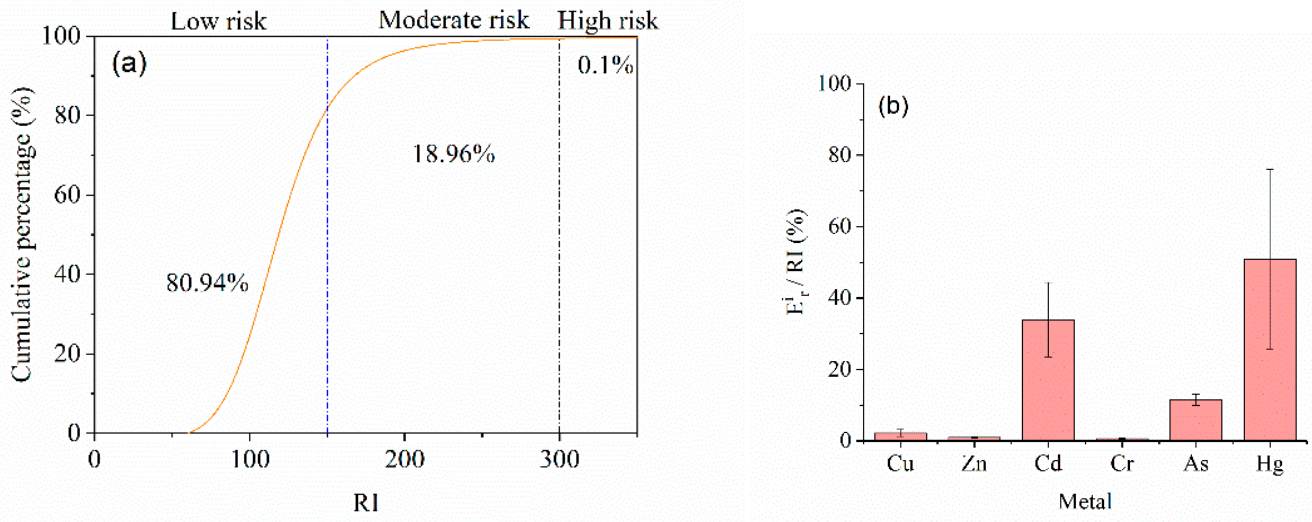

Figure 5. (a) The cumulative percentage of RI and (b) the contribution of respective heavy metal to RI in Daya Bay.

\subsection{Health Risk Assessment}

The EDI of the heavy metals determined as described above are shown in Table 5. For both adults and children, EDI values were below the acceptable daily intake (ADI) and $\mathrm{HQ}$ values were generally in decreasing order as follows: $\mathrm{Hg}>\mathrm{As}>\mathrm{Cu}>\mathrm{Cd}>$ $\mathrm{Zn}>\mathrm{Cr}$, and the $\mathrm{CR}$ values for different metals generally followed as $\mathrm{As}>\mathrm{Cr}>\mathrm{Cd}$. Monte Carlo simulation was used to evaluate the total noncarcinogenic risks (THQ) and carcinogenic risks (TCR) (Figure 6a,b). Potential risks were indicated by the probabilities corresponding to THQ values higher than 1 (THQ > 1). It was found that there was no potential noncarcinogenic risk for adults and children. But for total carcinogenic risks, the probability of adult and children exceeded the unacceptable risk value $\left(1 \times 10^{-4}\right)$ at $11.19 \%$ and $22.27 \%$, respectively. Therefore, the continuous or excessive intake of these marine organisms could cause chronic carcinogenic effects. The health risk results were comparable to the results reported by Yuan et al. [10]. It should be noted that the THQ and TCR used for risk assessment were based on the concentration addition of different metals, and their calculation is a noninteractive process. Humans are exposed to more than one pollutant and suffer combined or interactive effects [48]. However, THQ and TCR cannot directly reflect the true risk because they do not define any dose-response relationship [49]. Furthermore, the loss of elements caused by cooking and human intestinal absorption rate was not considered here.
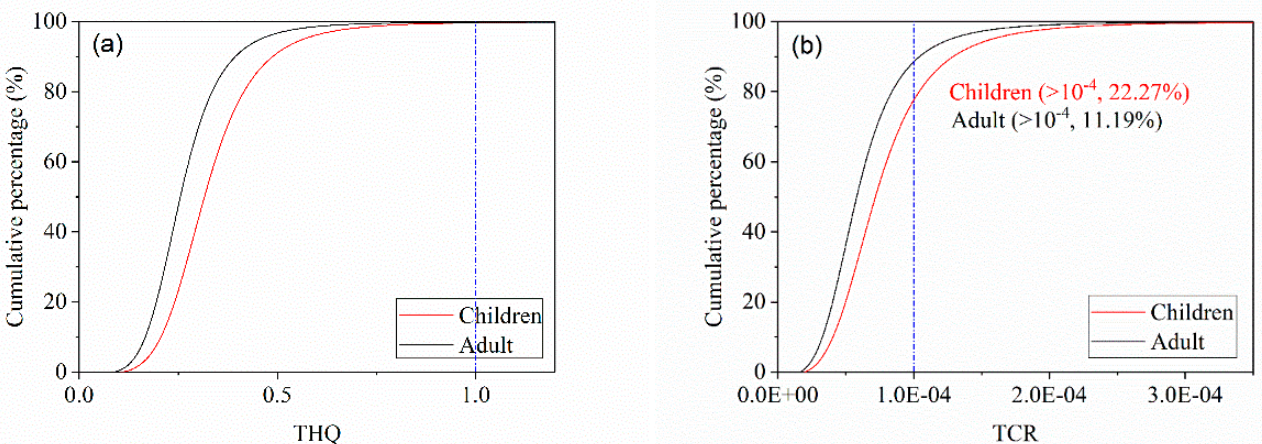

Figure 6. Cumulative percentage of (a) carcinogenic and (b) noncarcinogenic risks of eating marine organisms in Daya Bay. 
Table 5. Daily intakes of heavy metals in marine organisms consumed by adults and children in Guangdong province.

\begin{tabular}{|c|c|c|c|c|c|c|c|c|}
\hline \multirow{2}{*}{ Metals } & \multirow{2}{*}{ Mean Concentration ${ }^{1}(\mathrm{mg} / \mathrm{kg})$} & \multicolumn{2}{|c|}{ EDI (mg/kg/day) } & \multirow{2}{*}{$\begin{array}{c}\mathrm{ADI}^{2} \\
\text { (mg/kg/day) }\end{array}$} & \multicolumn{2}{|c|}{ HQ } & \multicolumn{2}{|c|}{ CR } \\
\hline & & Adult & Children & & Adult & Children & Adult & Children \\
\hline $\mathrm{Cu}$ & 5.7 & $1.96 \times 10^{-3}$ & $2.43 \times 10^{-3}$ & $5.00 \times 10^{-1}$ & $4.91 \times 10^{-2}$ & $6.07 \times 10^{-2}$ & & \\
\hline $\mathrm{Zn}$ & 17.6 & $8.33 \times 10^{-3}$ & $1.03 \times 10^{-2}$ & $3.00 \times 10^{-1}$ & $2.78 \times 10^{-2}$ & $3.43 \times 10^{-2}$ & & \\
\hline $\mathrm{Cd}$ & 0.085 & $4.66 \times 10^{-5}$ & $5.77 \times 10^{-5}$ & $1.00 \times 10^{-3}$ & $4.66 \times 10^{-2}$ & $5.77 \times 10^{-2}$ & $1.77 \times 10^{-5}$ & $2.19 \times 10^{-5}$ \\
\hline $\mathrm{Cr}$ & 0.09 & $3.61 \times 10^{-5}$ & $4.47 \times 10^{-5}$ & $3.30 \times 10^{-3}$ & $1.20 \times 10^{-2}$ & $1.49 \times 10^{-2}$ & $1.81 \times 10^{-5}$ & $2.23 \times 10^{-5}$ \\
\hline As & 0.4 & $1.95 \times 10^{-5}$ & $2.42 \times 10^{-5}$ & $3.10 \times 10^{-4}$ & $6.52 \times 10^{-2}$ & $8.06 \times 10^{-2}$ & $2.93 \times 10^{-5}$ & $3.63 \times 10^{-5}$ \\
\hline $\mathrm{Hg}$ & 0.016 & $7.32 \times 10^{-6}$ & $9.05 \times 10^{-6}$ & $2.30 \times 10^{-4}$ & $7.32 \times 10^{-2}$ & $9.05 \times 10^{-2}$ & & \\
\hline
\end{tabular}

${ }^{1}$ Average wet weight concentrations calculated after conversion from dry weight. ${ }^{2}$ Acceptable daily intake [6]. 
Figure 7 presents the sensitive analysis results of the metals concentrations of THQ and TCR estimates for humans. The highest contribution to THQ was $\mathrm{Hg}(28.45 \%)$, followed by $\mathrm{Cd}(22.75 \%), \mathrm{Cu}(22.67 \%)$, and As (17.84\%). Noncarcinogenic risks of $\mathrm{Hg}$ are also expected, because $\mathrm{Hg}$ exposure to human is believed to be significantly correlated with the consumption of fish among all food stuffs [8,50]. The contribution of As, $\mathrm{Cd}$, and $\mathrm{Cr}$ to the TCR value was relatively similar, with the highest being As (37.16\%), followed by $\mathrm{Cd}(32.47 \%)$ and $\mathrm{Cr}(30.37 \%)$, respectively. The carcinogenic health risk results of children and adults simulated by Monte Carlo warn people to pay more attention to the contents of carcinogenic elements in marine organisms. There were reports that the enrichment and amplification of heavy metals in organisms will harm human health through the food chain. For example, As can cause diseases of the cardiovascular system, central nervous system, and hematopoietic system [24]. Cd can lead to high blood pressure, high risk of fracture [51], and liver dysfunction [9]. Cr is involved in lipid metabolism and insulin function, and can cause damage to DNA and tissue structure [52]. Additionally, Table 1 presented that the concentrations of $\mathrm{Cr}$, As, and $\mathrm{Cd}$ in mollusks were higher. Crustaceans have the highest concentrations of $\mathrm{Cu}, \mathrm{Zn}$, and $\mathrm{Cd}$, and fish have the highest concentrations of $\mathrm{Hg}$. Therefore, mollusks were the main species that caused carcinogenic risk. Since the food habits could not be easily changed, and seafood was also the main source of protein for residents in coastal areas, on the basis of the same overall consumption of seafood, the carcinogenic risk can be maintained below a safe level by reducing the intake of mollusks and supplementing the intake of crustaceans. Moreover, the intake of crustaceans also contributed to the supplement of $\mathrm{Zn}$ in the human body. $\mathrm{Cu}$ and $\mathrm{Zn}$ were trace elements necessary for life activities. The moderate intake of $\mathrm{Zn}$ from marine organisms may therefore promote health [53].

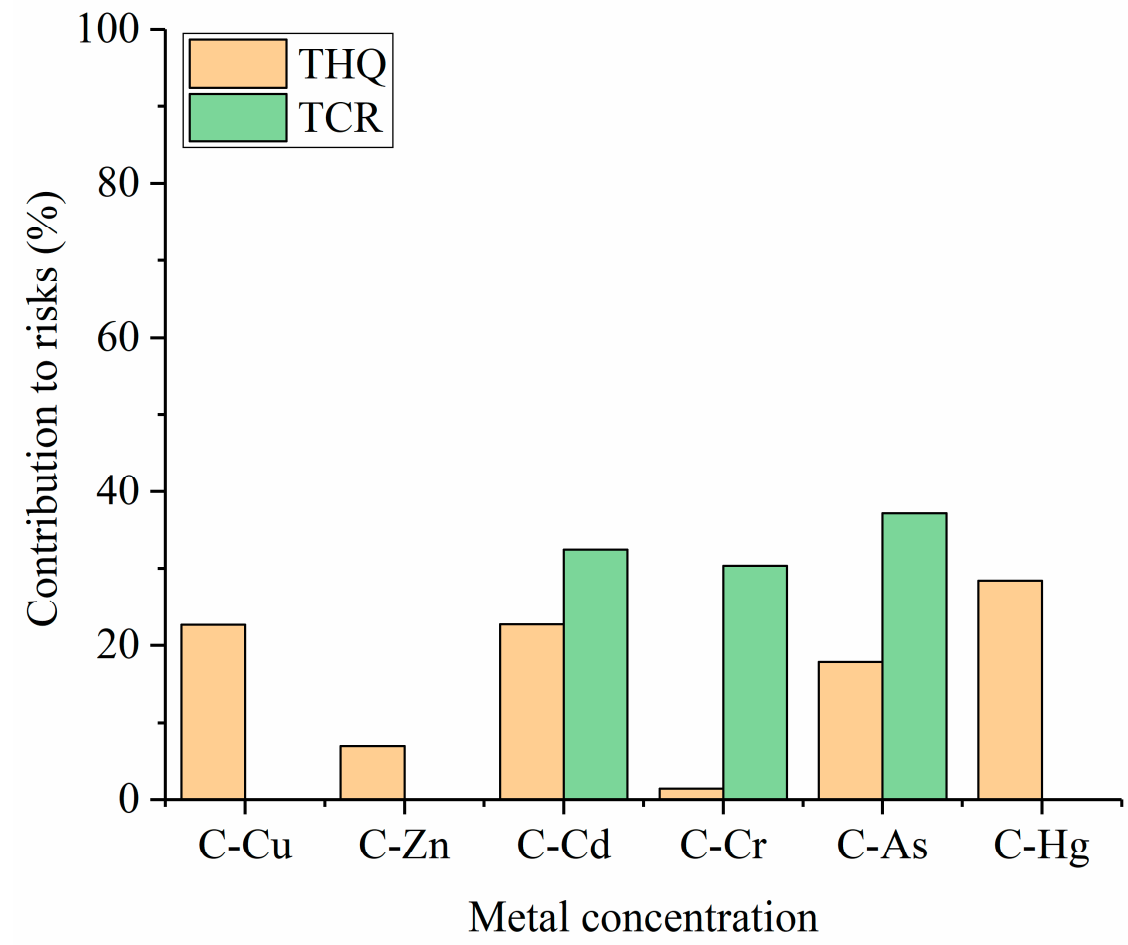

Figure 7. Sensitivity analyses of heavy metal concentration $\left(C_{m}\right)$ for a total hazard quotient and cancer risk.

\subsection{Limitations}

For heavy metals in sediments, only certain sampling points were used to estimate the overall risk of the area, and the results were usually uncertain, especially when the study area is large and there are many pollution sources. A Monte Carlo method, based on mathematical statistics and probability theory, was used to estimate the distribution of 
metal concentrations for the purpose of evaluating uncertainty in environmental risk models caused by random sampling [54]. However, the traditional Hakanson risk assessment method does not incorporate the ecosystem (species and their ecological functions) into the RI as a whole [22]. Therefore, the evaluation results cannot determine the ecological components that may be affected by heavy metals, and specify the species that need to be clearly protected. In addition, due to the spatial heterogeneity of soil/sediment, although the evaluation results can reflect the uncertainty of the contamination degree in the study area to a certain extent, it cannot combine geographic information to reveal the temporal and spatial distribution of contamination in the entire region. Moreover, the background information, such as the influence of $\mathrm{pH}, \mathrm{Eh}$, and SPM in sediments on the toxic effects of heavy metals, should also be taken into consideration.

It should be pointed out that although this study collected representative economic marine organisms in Daya Bay, the evaluation results do not represent all marine species. In addition, heavy metals can be enriched through the food chains and endanger human health. Therefore, the bioavailability and chemical speciation of heavy metals are also key factors affecting risk assessment [55]. The measurement in this study was the total concentration of marine organisms. Although the concentration and bioavailability of heavy metals have been treated with reference to a large number of previous studies, the results of the risk assessment were still uncertain. Moreover, risk models and key exposure parameters $\left(C_{m}, B W, I R, R f D\right.$, and $\left.S F\right)$ are also two main sources that affect the evaluation results [28]. The R $f \mathrm{D}$ and SF based upon the Integrated Risk Information System and International Agency for Research on Cancer might not yield a precise picture of current toxic responses of the Chinese population [29]. On the other hand, more precise health risks should consider the biological half-life of heavy metals, as well as the differences in the interaction and metabolic processes of heavy metals in the human body.

\section{Conclusions}

This study combined Monte Carlo simulation with risk assessment methods, and converted the traditional single point calculations into the probability distribution of risk description, providing a more comprehensive and objective assessment result of the heavy metal contamination in Daya Bay. The contents of heavy metals in the sediments of Daya Bay were lower than that in other regions of China. However, from the evaluation results of $\mathrm{I}_{\text {geo }}$ and RI, Daya Bay sediment was found to be most seriously contaminated with $\mathrm{Hg}$, which reached moderate pollution and accounted for $50.85 \%$ of the potential ecological risk, followed by $\mathrm{Cd}$ and As, which were unpolluted to moderately polluted, accounting for $33.92 \%$ and $11.47 \%$ of the potential ecological risk, respectively. Although the consumption of marine organisms in Daya Bay would not cause noncarcinogenic risks to the human body, the probability that the carcinogenic risk of adults and children exceeded the threshold $\left(1 \times 10^{-4}\right)$ was $11.19 \%$ and $22.27 \%$, respectively. Sensitivity analysis pointed out that the contribution of carcinogenic elements to risk can be arranged in descending order as As > $\mathrm{Cd}>\mathrm{Cr}$. In summary, efforts to control and remediate extensive heavy metal contamination in the Daya Bay should focus on $\mathrm{Hg}$, As, and Cd. Taking into account the uncertainty of the concentration information and the parameters in the evaluation models, the risk assessment of the coastal marine environment and human health should focus on the analysis of the bioavailability and toxic interaction of heavy metals in the future.

Supplementary Materials: The following are available online at https:/ / www.mdpi.com/2077-131 2/9/1/17/s1, Table S1: List and information of marine organisms sampled in the Daya Bay., Table S2: Seven classes of the geo-accumulation index., Table S3: Uncertain concentration $(\mathrm{mg} / \mathrm{kg})$ of heavy metals in sediments and marine organisms in Daya Bay., Table S4: Statistical results of $\mathrm{I}_{\text {geo }}$ and RI based on Monte Carlo simulation., Table S5: Category of potential ecological risks.

Author Contributions: H.H. conceived and designed the research proposals; Z.K. performed the experiments and analyzed the data, and the writing of the original draft; Y.G. and Y.R. contributed to 
the review and revision guidance of the paper. All authors have read and agreed to the published version of the manuscript.

Funding: This work was supported by the Key Special Project for Introduced Talents Team of Southern Marine Science and Engineering Guangdong Laboratory (Guangzhou) (GML2019ZD0402), and the Central Public-interest Scientific Institution Basal Research Fund, CAFS (NO.2020TD15).

Informed Consent Statement: Informed consent was obtained from all subjects involved in the study.

Data Availability Statement: The data presented in this study are available on request from the corresponding authors.

Acknowledgments: The authors appreciate the assistant of our group members in the sampling and experiments. We also grateful to the editors and anonymous reviewers for helpful comments on the manuscript.

Conflicts of Interest: The authors declare no conflict of interest.

\section{References}

1. Gu, Y.-G.; Lin, Q.; Wang, X.-H.; Du, F.-Y.; Yu, Z.-L.; Huang, H.-H. Heavy metal concentrations in wild fishes captured from the South China Sea and associated health risks. Mar. Pollut. Bull. 2015, 96, 508-512. [CrossRef] [PubMed]

2. Wang, X.-N.; Gu, Y.-G.; Wang, Z.-H.; Ke, C.-L.; Mo, M.-S. Biological risk assessment of heavy metals in sediments and health risk assessment in bivalve mollusks from Kaozhouyang Bay, South China. Mar. Pollut. Bull. 2018, 133, 312-319. [CrossRef] [PubMed]

3. Vicente-Martorell, J.J.; Galindo-Riaño, M.D.; García-Vargas, M.; Granado-Castro, M.D. Bioavailability of heavy metals monitoring water, sediments and fish species from a polluted estuary. J. Hazard. Mater. 2009, 162, 823-836. [CrossRef] [PubMed]

4. Gu, Y.-G.; Wang, X.-N.; Lin, Q.; Du, F.-Y.; Ning, J.-J.; Wang, L.-G.; Li, Y.-F. Fuzzy comprehensive assessment of heavy metals and $\mathrm{Pb}$ isotopic signature in surface sediments from a bay under serious anthropogenic influences: Daya Bay, China. Ecotoxicol. Environ. Saf. 2016, 126, 38-44. [CrossRef]

5. Liu, J.-J.; Ni, Z.-X.; Diao, Z.-H.; Hu, Y.-X.; Xu, X.-R. Contamination level, chemical fraction and ecological risk of heavy metals in sediments from Daya Bay, South China Sea. Mar. Pollut. Bull. 2018, 128, 132-139. [CrossRef] [PubMed]

6. Gu, Y.-G.; Huang, H.-H.; Lin, Q. Concentrations and human health implications of heavy metals in wild aquatic organisms captured from the core area of Daya Bay's Fishery Resource Reserve, South China Sea. Environ. Toxicol. Pharmacol. 2016, 45, 90-94. [CrossRef] [PubMed]

7. Baki, M.A.; Hossain, M.M.; Akter, J.; Quraishi, S.B.; Haque Shojib, M.F.; Atique Ullah, A.K.M.; Khan, M.F. Concentration of heavy metals in seafood (fishes, shrimp, lobster and crabs) and human health assessment in Saint Martin Island, Bangladesh. Ecotoxicol. Environ. Saf. 2018, 159, 153-163. [CrossRef]

8. Bonsignore, M.; Salvagio Manta, D.; Mirto, S.; Quinci, E.M.; Ape, F.; Montalto, V.; Gristina, M.; Traina, A.; Sprovieri, M. Bioaccumulation of heavy metals in fish, crustaceans, molluscs and echinoderms from the Tuscany coast. Ecotoxicol. Environ. Saf. 2018, 162, 554-562. [CrossRef]

9. Rahman, M.S.; Molla, A.H.; Saha, N.; Rahman, A. Study on heavy metals levels and its risk assessment in some edible fishes from Bangshi River, Savar, Dhaka, Bangladesh. Food Chem. 2012, 13, 1847-1854. [CrossRef]

10. Yuan, Y.; Sun, T.; Wang, H.; Liu, Y.; Pan, Y.; Xie, Y.; Huang, H.; Fan, Z. Bioaccumulation and health risk assessment of heavy metals to bivalve species in Daya Bay (South China Sea): Consumption advisory. Mar. Pollut. Bull. 2020, 150, 110717. [CrossRef]

11. Zhang, Y.; Lu, X.; Wang, N.; Xin, M.; Geng, S.; Jia, J.; Meng, Q. Heavy metals in aquatic organisms of different trophic levels and their potential human health risk in Bohai Bay, China. Environ. Sci. Pollut. Res. 2016, 23, 17801-17810. [CrossRef] [PubMed]

12. Gu, Y.-G.; Wang, Z.-H.; Lu, S.-H.; Jiang, S.-J.; Mu, D.-H.; Shu, Y.-H. Multivariate statistical and GIS-based approach to identify source of anthropogenic impacts on metallic elements in sediments from the mid Guangdong coasts, China. Environ. Pollut. 2012, 163, 248-255. [CrossRef] [PubMed]

13. Yang, J.; Cao, L.; Wang, J.; Liu, C.; Huang, C.; Cai, W.; Fang, H.; Peng, X. Speciation of Metals and Assessment of Contamination in Surface Sediments from Daya Bay, South China Sea. Sustainability 2014, 6, 9096-9113. [CrossRef]

14. Chen, T.-R.; Yu, K.-F.; Li, S.; Price, G.J.; Shi, Q.; Wei, G.-J. Heavy metal pollution recorded in Porites corals from Daya Bay, northern South China Sea. Mar. Environ. Res. 2010, 70, 318-326. [CrossRef] [PubMed]

15. Du, J.; Mu, H.; Song, H.; Yan, S.; Gu, Y.; Zhang, J. 100 years of Sediment History of Heavy Metals in Daya Bay, China. Water. Air. Soil Poll. 2008, 190, 343-351. [CrossRef]

16. Xiao, K.; Li, H.; Shananan, M.; Zhang, X.; Wang, X.; Zhang, Y.; Zhang, X.; Liu, H. Coastal water quality assessment and groundwater transport in a subtropical mangrove swamp in Daya Bay, China. Sci. Total Environ. 2019, 646, 1419-1432. [CrossRef]

17. Qiu, Y.-W. Bioaccumulation of heavy metals both in wild and mariculture food chains in Daya Bay, South China. Estuar. Coast. Shelf Sci. 2015, 163, 7-14. [CrossRef]

18. Corazza, M.Z.; Abrao, T.; Lepri, F.G.; Gimenez, S.M.N.; Oliveira, E.; Josefa Santos, M. Monte Carlo method applied to modeling copper transport in river sediments. Stoch. Environ. Res. Risk Assess. 2012, 26, 1063-1079. [CrossRef]

19. Zhao, G.; Ye, S.; Yuan, H.; Ding, X.; Wang, J. Distribution and contamination of heavy metals in surface sediments of the Daya Bay and adjacent shelf, China. Mar. Pollut. Bull. 2016, 112, 420-426. [CrossRef] 
20. Lao, Q.; Su, Q.; Liu, G.; Shen, Y.; Chen, F.; Lei, X.; Qing, S.; Wei, C.; Zhang, C.; Gao, J. Spatial distribution of and historical changes in heavy metals in the surface seawater and sediments of the Beibu Gulf, China. Mar. Pollut. Bull. 2019, 146, 427-434. [CrossRef]

21. Håkanson, L. An Ecological Risk Index for Aquatic Pollution Control-A Sedimentological Approach. Water Res. 1980, 14, 975-1001. [CrossRef]

22. Qu, C.; Li, B.; Wu, H.; Wang, S.; Li, F. Probabilistic ecological risk assessment of heavy metals in sediments from China's major aquatic bodies. Stoch. Environ. Res. Risk Assess. 2015, 30, 271-282. [CrossRef]

23. Guo, J.; Wu, F.; Shen, R.; Zeng, E.Y. Dietary intake and potential health risk of DDTs and PBDEs via seafood consumption in South China. Ecotoxicol. Environ. Saf. 2010, 73, 1812-1819. [CrossRef] [PubMed]

24. Hertzberg, R.; Choudhury, H.; Rice, G.; Cogliano, J.; Mukerjee, D.; Teuschler, L. Supplementary Guidance for Conducting Health Risk Assessment of Chemical Mixtures; Risk Assessment Forum Technical Panel: Washington, DC, USA, 2000.

25. Lei, B.; Chen, L.; Hao, Y.; Cao, T.; Zhang, X.; Yu, Y.; Fu, J. Trace elements in animal-based food from Shanghai markets and associated human daily intake and uptake estimation considering bioaccessibility. Ecotoxicol. Environ. Saf. 2013, 96, 160-167. [CrossRef] [PubMed]

26. Gu, Y.-G.; Ning, J.-J.; Ke, C.-L.; Huang, H.-H. Bioaccessibility and human health implications of heavy metals in different trophic level marine organisms: A case study of the South China Sea. Ecotoxicol. Environ. Saf. 2018, 163, 551-557. [CrossRef]

27. Chen, Q.; Pan, X.-D.; Huang, B.-F.; Han, J.-L. Distribution of metals and metalloids in dried seaweeds and health risk to population in southeastern China. Sci. Rep. 2018, 8, 3578. [CrossRef]

28. Chen, G.; Wang, X.; Wang, R.; Liu, G. Health risk assessment of potentially harmful elements in subsidence water bodies using a Monte Carlo approach: An example from the Huainan coal mining area, China. Ecotoxicol. Environ. Saf. 2019, 171, 737-745. [CrossRef]

29. Yang, S.; Zhao, J.; Chang, S.X.; Collins, C.; Xu, J.; Liu, X. Status assessment and probabilistic health risk modeling of metals accumulation in agriculture soils across China: A synthesis. Environ. Int. 2019, 128, 165-174. [CrossRef]

30. Macdonald, D.D.; Ingersoll, C.G.; Berger, T.A. Development and evaluation of consensus-based sediment quality guidelines for freshwater ecosystems. Arch. Environ. Contam. Toxicol. 2000, 39, 20-31. [CrossRef]

31. Ding, X.; Ye, S.; Laws, E.A.; Mozdzer, T.J.; Yuan, H.; Zhao, G.; Yang, S.; He, L.; Wang, J. The concentration distribution and pollution assessment of heavy metals in surface sediments of the Bohai Bay, China. Mar. Pollut. Bull. 2019, 149, 110497. [CrossRef]

32. Hao, Z.; Chen, L.; Wang, C.; Zou, X.; Zheng, F.; Feng, W.; Zhang, D.; Peng, L. Heavy metal distribution and bioaccumulation ability in marine organisms from coastal regions of Hainan and Zhoushan, China. Chemosphere 2019, 226, 340-350. [CrossRef] [PubMed]

33. Liang, X.; Song, J.; Duan, L.; Yuan, H.; Li, X.; Li, N.; Qu, B.; Wang, Q.; Xing, J. Source identification and risk assessment based on fractionation of heavy metals in surface sediments of Jiaozhou Bay, China. Mar. Pollut. Bull. 2018, 128, 548-556. [CrossRef] [PubMed]

34. Wang, J.; Ye, S.; Laws, E.A.; Yuan, H.; Ding, X.; Zhao, G. Surface sediment properties and heavy metal pollution assessment in the Shallow Sea Wetland of the Liaodong Bay, China. Mar. Pollut. Bull. 2017, 120, 347-354. [CrossRef] [PubMed]

35. Yu, R.; Zhang, W.; Hu, G.; Lin, C.; Yang, Q. Heavy metal pollution and Pb isotopic tracing in the intertidal surface sediments of Quanzhou Bay, southeast coast of China. Mar. Pollut. Bull. 2016, 105, 416-421. [CrossRef]

36. Pedersen, F.; Bjørnestad, E.; Andersen, H.V.; Kjølholt, J.; Poll, C. Characterization of sediments from Copenhagen Harbour by use of biotests. Water Sci. Technol. 1998, 37, 233-240. [CrossRef]

37. Beltrame, M.O.; De Marco, S.G.; Marcovecchio, J.E. Influences of Sex, Habitat, and Seasonality on Heavy-Metal Concentrations in the Burrowing Crab (Neohelice Granulata) From a Coastal Lagoon in Argentina. Arch. Environ. Contam. Toxicol. 2010, 58, 746-756. [CrossRef]

38. Yilmaz, A.B.; Yılmaz, L. Influences of sex and seasons on levels of heavy metals in tissues of green tiger shrimp (Penaeus semisulcatus de Hann, 1844). Food Chem. 2007, 101, 1664-1669. [CrossRef]

39. FAO. Compilation of Legal Limits for Hazardous Substances in Fish and Fishery Products; Organization, Food and Agriculture Organization of the United Nations, Ed.; Food and Agriculture Organization of the United Nations: Rome, Italy, 1983; pp. 5-10.

40. Liu, J.; Cao, L.; Dou, S. Bioaccumulation of heavy metals and health risk assessment in three benthic bivalves along the coast of Laizhou Bay, China. Mar. Pollut. Bull. 2017, 117, 98-110. [CrossRef]

41. Peng, F.; Yin, J.; Wang, Q.; Ni, T.; Lin, J.; Li, J. Occurrence and risk assessment of heavy metals and polycyclic aromatic hydrocarbons in marine organisms from Yuwai Fishing Ground (in Chinese). Asian J. Ecotoxicol. 2019, 14, 168-179.

42. Liu, Q.; Xu, X.; Zeng, J.; Shi, X.; Liao, Y.; Du, P.; Tang, Y.; Huang, W.; Chen, Q.; Shou, L. Heavy metal concentrations in commercial marine organisms from Xiangshan Bay, China, and the potential health risks. Mar. Pollut. Bull. 2019, 141, 215-226. [CrossRef]

43. Gu, Y.-G.; Huang, H.-H.; Liu, Y.; Gong, X.-Y.; Liao, X.-L. Non-metric multidimensional scaling and human risks of heavy metal concentrations in wild marine organisms from the Maowei Sea, the Beibu Gulf, South China Sea. Environ. Toxicol. Pharmacol. 2018, 59, 119-124. [CrossRef] [PubMed]

44. Liu, Q.; Liao, Y.; Shou, L. Concentration and potential health risk of heavy metals in seafoods collected from Sanmen Bay and its adjacent areas, China. Mar. Pollut. Bull. 2018, 131, 356-364. [CrossRef] [PubMed]

45. Raknuzzaman, M.; Ahmed, M.K.; Islam, M.S.; Habibullah-Al-Mamun, M.; Tokumura, M.; Sekine, M.; Masunaga, S. Trace metal contamination in commercial fish and crustaceans collected from coastal area of Bangladesh and health risk assessment. Environ. Sci. Pollut. Res. Int. 2016, 23, 17298-17310. [CrossRef] [PubMed] 
46. Huang, D.; Xue, W.; Zeng, G.; Wan, J.; Chen, G.; Huang, C.; Zhang, C.; Cheng, M.; Xu, P. Immobilization of Cd in river sediments by sodium alginate modified nanoscale zero-valent iron: Impact on enzyme activities and microbial community diversity. Water Res. 2016, 106, 15-25. [CrossRef] [PubMed]

47. Zhu, Y.-G.; Gillings, M.; Simonet, P.; Stekel, D.; Banwart, S.; Penuelas, J. Microbial mass movements. Science 2017, 357, 1099-1100. [CrossRef]

48. Li, J.; Huang, Z.Y.; Hu, Y.; Yang, H. Potential risk assessment of heavy metals by consuming shellfish collected from Xiamen, China. Environ. Sci. Pollut. Res. 2013, 20, 2937-2947. [CrossRef] [PubMed]

49. USEPA. Risk Assessment Guidance for Superfund Volume I: Human Health Evaluation Manual (Part A). 1989. Available online: https:/ / www.epa.gov/sites/production/files/2015-09/documents/rags_a.pdf (accessed on 9 November 2020).

50. Mortazavi, S.M.J.; Mortazavi, G.; Paknahad, M. A review on the distribution of $\mathrm{Hg}$ in the environment and its human health impacts. J. Hazard. Mater. 2016, 310, 278-279. [CrossRef]

51. Alamdar, A.; Eqani, S.A.M.A.S.; Hanif, N.; Ali, S.M.; Fasola, M.; Bokhari, H.; Katsoyiannis, I.A.; Shen, H. Human exposure to trace metals and arsenic via consumption of fish from river Chenab, Pakistan and associated health risks. Chemosphere 2017, 168, 1004-1012. [CrossRef]

52. Ahmed, M.K.; Shaheen, N.; Islam, M.S.; Habibullah-al-Mamun, M.; Islam, S.; Mohiduzzaman, M.; Bhattacharjee, L. Dietary intake of trace elements from highly consumed cultured fish (Labeo rohita, Pangasius pangasius and Oreochromis mossambicus) and human health risk implications in Bangladesh. Chemosphere 2015, 128, 284-292. [CrossRef]

53. Plum, L.M.; Rink, L.; Haase, H. The essential toxin: Impact of zinc on human health. Int. J. Environ. Res. Public Health 2010, 7, 1342-1365. [CrossRef]

54. Qu, L.; Huang, H.; Xia, F.; Liu, Y.; Dahlgren, R.A.; Zhang, M.; Mei, K. Risk analysis of heavy metal concentration in surface waters across the rural-urban interface of the Wen-Rui Tang River, China. Environ. Pollut. 2018, 237, 639-649. [CrossRef] [PubMed]

55. Oomen, A.; Hack, A.; Minekus, M.; Zeijdner, E.E.; Cornelis, C.; Schoeters, G.; Verstraete, W.; Van de Wiele, T.; Wragg, J.; Rompelberg, C.; et al. Comparison of five in vitro digestion models to study the bioaccessibility of soil contaminants. Environ. Sci. Technol. 2002, 36, 3326-3334. [CrossRef] [PubMed] 